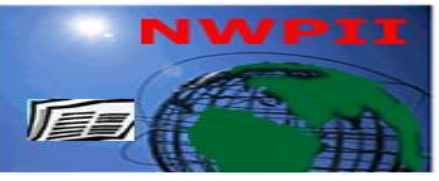

American Journal of Biomedical Sciences

ISSN: 1937-9080

nwpii.com/ajbms

\title{
Vaspin Improves Experimental Isoproterenol-induced Heart Failure in Rats
}

\author{
Suzan M. M. Moursi, M.D ${ }^{1}$ Wesam M. R. Ashour, M.D ${ }^{1}$, Radwa M. A. Elbelbesy, M.D ${ }^{2}$ \\ ${ }^{1}$ Medical Physiology Department, Faculty of Medicine, Zagazig University, Egypt. \\ ${ }^{2}$ Cardiology Department, Faculty of Medicine, Zagazig University, Egypt. \\ *Corresponding Author \\ Wesam M. R. Ashour \\ Medical Physiology Department, \\ Faculty of Medicine, \\ Zagazig University \\ Egypt \\ E-mail:wesam_ashour@yahoo.com
}

Received:23 March 2019; | Revised:02 May 2019; | Accepted: 01 September 2019

\section{Abstract}

Background: Chronic heart failure (CHF) is the end result of the majority of cardiovascular diseases and despite the progress in treatment methods during the past two decades, its total morbidity and mortality remains high. Low serum vaspin level is associated with an increase of major adverse cardiac events risk, however, to date; no studies have been elaborated to determine the effects of vaspin administration on heart failure (HF).

Objective: This study was conducted to examine the possible protective effects of vaspin on isoproterenol-induced chronic heart failure in rats and to explore the possible related mechanisms.

Materials and methods: Thirty healthy adult male albino rats of initial body weight $215-241 \mathrm{~g}$ were included in the study. Rats were randomly and equally divided into 3 groups: Group (I): vehicle treated control group, group (II): experimental isoproterenol-induced HF group, and group (III): experimental isoproterenol-induced HF treated by vaspin group. Rats were examined for echocardiographic evaluation of heart function, the serum levels of lactate dehydrogenase (LDH), creatine phosphokinase-muscle/brain (CPK-MB) and cardiac troponin I (cTnI) and cardiac superoxide dismutase (SOD), catalase (CAT), glutathione peroxidase (GPx), malondialdehyde (MDA), nitric oxide (NO) as well as the levels of cardiac tumour necrosis factor alpha (TNF- a ) and interleukin-6 (IL-6). Histopathological examination for cardiac tissues was also evaluated under Haematoxylin and Eosin and Masson's Trichome stains.

Results: The present study revealed that vaspin administration significantly improved the increased serum LDH, CPK-MB and cTnI, cardiac TNF- $a$, IL- 6 and MDA, left ventricular end diastolic diameter (LVEDD), left ventricular end systolic diameter (LVESD), heart weight and heart weight index observed in isoproterenol-induced CHF group. It also improved the decreased activity of cardiac SOD, CAT and GPx, cardiac NO, left ventricular fractional shortening (LVFS) as well as left ventricular ejection fraction (LVEF). Moreover, it improved cardiac hypertrophy and the myofibrillar degeneration and fibrosis observed in histopathological examination in isoproterenol-induced CHF group. 
Conclusion: The results of the current study indicated that vaspin inhibited the progression of cardiac degeneration, fibrosis and HF in experimental isoproterenol-induced CHF in rats.

Keywords: Cardiomyopathy, Heart failure, Vaspin, Inflammation

\section{Introduction}

Heart failure (HF) is a progressed end stage of various cardiac disorders and remains to be a major cause of morbidity and mortality ${ }^{[1]}$. The most prominent characteristics of heart failure are deterioration of active relaxation and contraction of the left ventricle, ventricular remodelling and hypertrophy and reduced ejection fraction ${ }^{[2]}$.

Myocardial ischemia is a basic cardiovascular disease that leads to myocardial fibrosis development and pathogenesis of ischemic cardiomyopathy, which contributes to systolic and diastolic dysfunctions ${ }^{[3]}$.

Isoproterenol (ISO), a synthetic catecholamine and $\beta$-adrenoceptor agonist, can result in cardiac hypertrophy, fibroblast proliferation, connective tissue accumulation with decreased myocardial compliance and inhibition of diastolic and systolic functions which are similar to the pathological and hemodynamic changes in human ${ }^{[4]}$.

Although current medical treatment options (such as digoxin, diuretics, angiotensin converting enzyme inhibitors, and beta blockers) are widely used, most of them can only provide symptomatic relief and remain insufficient in attenuating cardiovascular dysfunction ${ }^{[5]}$. So, new therapeutic approaches to attenuate heart failure progression are required.

It has been also elucidated that in addition to enhanced sympathetic excitability and abnormal secretion of various humoral factors in $\mathrm{CHF}$, overexpression of inflammatory cytokines and stimulation of the immune response are important features of its pathophysiology ${ }^{[6]}$. Disorders of the immune system are associated with cardiomyocyte death, fibrosis, systolic dysfunction and HF severity [7].Therefore, anti-inflammatory treatment for heart failure may act as a new approach ${ }^{[8]}$.

Vaspin, a visceral adipose tissue-derived serine protease inhibitor, is an adipokine with insulinsensitizing activity and was first identified in the visceral adipose tissues of genetically obese rats ${ }^{[9]}$. In vitro studies have demonstrated that vaspin exerts anti-inflammatory ${ }^{[10]}$ and anti-apoptotic effects ${ }^{[11]}$. It has also been found that vaspin may inhibit the proliferation and production of chemokines and reactive oxygen species (ROS) in vascular smooth muscle cells ${ }^{[12]}$. It also inhibited the progression of atherosclerotic plaques in atherosclerosis-prone apolipoprotein E (apoE-/-) deficient mice by inhibiting endoplasmic reticulum stress induced macrophage apoptosis ${ }^{[13]}$.

Moreover, it has been found that low serum vaspin is associated with coronary artery disease (CAD) and unstable angina pectoris and may serve as a biomarker for CAD ${ }^{[14]}$. It has also been found that Vaspin protects rats against myocardial ischemia/reperfusion injury through the Toll-like receptor 4 (TLR4)/ nuclear factor kappa light chain enhancer of activated B cells (NF- $\kappa$ B) signaling pathway ${ }^{[15]}$. However, until now, no studies have been performed to investigate the effect of vaspin on the progression of CHF.

Therefore, this study aimed to examine the predictive protective effects of vaspin on the progression of isoproterenol-induced chronic heart failure in rats and to explore its potential leading mechanisms. The levels of biomarkers of cardiac injury, inflammatory and lipid peroxidation markers, antioxidant enzyme activities, $\mathrm{NO}$ as well as cardiac histoarchitecture were examined in a trial to clarify possible involved mechanisms.

\section{Materials and Methods}

This study was conducted on 30 healthy adult male albino rats of local strain weighing 215-241g, were obtained from the animal house of Faculty of Veterinary Medicine- Zagazig University. Rats were kept in steel wire cages $(45 \times 30 \times 20 \mathrm{Cm}-5$ per cage) in the physiology animal house in Faculty of Medicine, Zagazig University, under hygienic conditions. They were fed the commercial rodent chow with free access to water, kept at room temperature and were maintained on a $12 \mathrm{~h}$ light/dark cycle. Rats were adapted to the new environment for one week before the experiment 
going on. The animal experiments were approved by the Institutional Research Board.

Rats were randomly assigned to three equal groups: Group (I): vehicle treated control group, rats were subcutaneously injected by $5 \mathrm{ml} / \mathrm{kg}$ physiological saline $(0.9 \%)$ once-daily for 7 successive days, group (II): experimental isoproterenol-induced HF group, rats were subcutaneously injected by isoproterenol (Isoproterenol hydrochloride, (CAS Number: 5130-9, provided by Sigma-Aldrich Co.) dissolved in physiological saline at a dose of $5 \mathrm{mg} / \mathrm{kg}$ body weight, once-daily for 7 successive days to induce myocardial fibrosis and HF [16], and group (III): experimental isoproterenol-induced HF treated by Vaspin group, vaspin (product number: SRP491525UG, provided by Sigma-Aldrich Co.) (1 $\mu$ $\mathrm{g} / \mathrm{kg} /$ day) was administered intraperitoneally for 2 weeks starting 1 week prior to induction of $\mathrm{HF}^{[17]}$. Rats in groups I and II were also administered intraperitoneal saline injection once daily for 2 weeks.

Body weights of all rats were noted in the beginning and at the end of the study.

The heart weight index (HWI; in $\mathrm{mg} / \mathrm{g}$ ) was measured by dividing the heart weight by body weight ${ }^{[16]}$.

Echocardiographic assessment of heart function: Rats were anesthetized with $30 \mathrm{mg} / \mathrm{kg}$ pentobarbital sodium and an ultrasound probe was placed in the left sternal border. Left ventricular end systolic diameter (LVESD), left ventricular end diastolic diameter (LVEDD), left ventricular fractional shortening (LVFS) and left ventricular ejection fraction (LVEF) were measured.

x 100 .

$$
\text { LVFS }(\%)=(\text { LVEDD }- \text { LVESD }) / L V E D D
$$

LVEF $(\%)=($ LVDV - LVSV $) / L V D V ~ x$ 100, where LVDV and LVSV are left ventricular end diastolic and end systolic volumes, respectively.

All evaluations were performed using Echocardiography, Hitachi Aloka Noblus 2013 Ultrasound, KE10938305, Japan.

Sample collection:

Blood samples were collected from retro orbital venous plexus, and serum was separated by centrifugation of blood at $3000 \mathrm{rpm}$ for 20 minutes and kept deep frozen at $\left(-20{ }^{\circ} \mathrm{C}\right)$ until used to measure the serum levels of lactate dehydrogenase
(LDH), creatine phosphokinase muscle/brain (CPK$\mathrm{MB})$, cardiac troponin I (cTnI). After collecting blood samples, the animals were sacrificed by cervical dislocation under mild ether anesthesia. The heart was excised immediately and rinsed in ice-cold saline, dried, weighed and then processed for biochemical and histopathological studies.

Serum biochemical Analysis:

1) Serum $\mathrm{LDH}$ level was measured using spectrophotometer (spectronic 3000 Array, Germany) using commercial kit (Catalog Number 279 001, provided by Egyptian Company for Biotechnology) according to the method of Kachmar \& Moss ${ }^{[18]}$.

2) Serum CPK-MB level was measured using commercial kit (CPK-MB Kit, Ultra Group, Egypt) according to the method of $\mathrm{Wu}$ et al. ${ }^{[19]}$.

3) Serum cTnI was measured using commercial kit (Catalog Number SE120134 provided by Sigma-Aldrich Co.) according to the method of Etievent et al. ${ }^{[20]}$.

Preparation of tissue homogenate:

A portion of the cardiac tissue was homogenized (potter-Elvehjem type homogenizer) with phosphate buffered solution (PBS, $7.4 \mathrm{pH}$ ), then centrifuged at $12000 \times \mathrm{g}$ for $10 \mathrm{~min}$ at $4^{\circ} \mathrm{C}$, the supernatant portion was used for measuring cardiac nitric oxide (NO), antioxidants like superoxide dismutase (SOD), catalase (CAT) and glutathione peroxidase (GPx) as well as lipid peroxidation product like malondialdehyde (MDA) and the levels of pro-inflammatory cytokines like tumour necrosis factor (TNF- $a$ ) and interleukins 6 (IL-6) ${ }^{[21]}$.

Assay of cardiac antioxidants and MDA: The levels of MDA, SOD, CAT and GPx were measured using a MDA, SOD ,CAT and GPx assay kits (Bio diagnostic, Egypt kits) according to Kakker et al ${ }^{[22]}$, Ohkawa et al ${ }^{[23]}$, Boveris and Chance ${ }^{[24]}$ and Paglia and Valentine ${ }^{[25]}$ respectively.

Assay of Cardiac inflammatory markers:

The levels of TNF- and IL-6 were measured by using ELISA kits (Bio diagnostic, Egypt kits) according to Bonavida [26] and Wang et al [27] respectively.

Assay of cardiac NO:

Cardiac NO level was measured using ELISA kit (Cat. N0. 11756281001 provided by SigmaAldrich Co.) according to Ghasemi et al. ${ }^{[28]}$. 
Histopathological examination:

Remaining cardiac tissue was fixed in $10 \%$ formalin, and then the specimens were dehydrated with a series of ascending grade ethanol from 75 to $100 \%$, placed, thereafter, in xylol and embedded in paraffin wax. Longitudinal sections $(5 \mu \mathrm{m}$ in thickness) processed on slides and stained with Haematoxylin and Eosin (H \& E) stain ${ }^{[29]}$ and also with Masson's Trichome (MT) stain to observe collagen fibers deposits ${ }^{[30]}$.

The stained slides were studied at a magnification of $\times 400$ under light microscope by a blinded pathologist.

Statistical Analysis:

The data obtained in the present study were expressed as mean SD for quantitative variables, and statistically analyzed by using SPSS program (version 18 for windows) (SPSS Inc. Chicago, IL, USA). One way analysis of variance (ANOVA) was used to compare the results of all examined groups followed by student's least significant deferances (LSD) test to compare statistical differences between groups. $\mathrm{P}$ value $<0.05$ was considered statistically significant.

\section{Results}

The present study showed that isoproterenol significantly increased LVESD, LVEDD, heart weight and heart weight index, serum LDH, CPKMB, cTnI, cardiac MDA, IL-6 and TNF- a levels $(p<0.001)$ but significantly decreased LVFS, LVEF, cardiac NO, SOD, CAT and GSH-Px levels $(p<0.001)$ in ISO-treated group in comparison to the normal control group with no significant change in final body weight $(\mathrm{P}>0.05)$ [Tables $1-4$ and figure 1 (A , B)] Moreover, histopathological examination revealed marked degeneration and distribution of myocytes with proliferation of intervening collagen fibers and inflammatory cells infiltration [figure 2 (A, B) and figure $3(\mathrm{~A}, \mathrm{~B})$ ].

On the other hand, it was found that vaspin administration resulted in a significant decrease in LVESD, LVEDD $(p<0.001)$, heart weight and heart weight index $(p<0.01)$, serum LDH, CPK-MB, cTnI, cardiac MDA, IL-6 and TNF- $\alpha$ levels $(p<0.001)$ but significantly increased LVFS, LVEF, cardiac NO, SOD, CAT and GSH-Px levels $(\mathrm{p}<0.001)$ in vaspin treated ISO group when compared to ISO untreated group [Tables 1-4 and figure 1C] It was also found that vaspin improved the histopathological changes observed in ISO induced $\mathrm{HF}$ group [figure $2 \mathrm{C}$ and figure $3 \mathrm{C}$ ].

Table 1: body weight, heart weight and heart weight index (HWI) in all studied groups

\begin{tabular}{|c||c||c||c||c||}
\hline \hline \multicolumn{2}{|c||}{ Groups } & $\begin{array}{c}\text { Group I } \\
\text { (control) }\end{array}$ & $\begin{array}{c}\text { Group II } \\
\text { Parameters }\end{array}$ & $\begin{array}{c}\text { Group III } \\
\text { ( HF treated by vaspin) }\end{array}$ \\
\hline $\begin{array}{c}\text { Body weight } \\
(\mathrm{gm})\end{array}$ & $\overline{\mathrm{X}} \pm \mathrm{SD}$ & $239.3 \pm 7.36$ & $238.6 \pm 8.51$ & $240.5 \pm 5.64$ \\
\hline Heart weight (gm) & $\overline{\mathrm{X}} \pm \mathrm{SD}$ & $1.16 \pm 0.4$ & $1.46 \pm 0.06^{\mathrm{a}^{* * *}}$ & $1.30 \pm 0.04^{\mathrm{a}^{* * *} \mathrm{~b}^{* * *}}$ \\
\hline HWI $(\mathrm{mg} / \mathrm{gm})$ & $\overline{\mathrm{X}} \pm \mathrm{SD}$ & $4.8 \pm 0.12$ & $6.13 \pm 0.45^{\mathrm{a}^{* * *}}$ & $5.42 \pm 0.24^{\mathrm{a}^{* *} \mathrm{~b}^{* * *}}$ \\
\hline
\end{tabular}

$\mathrm{a}=$ versus group $\mathrm{I} ; \mathrm{b}=$ versus group $\mathrm{II} ; *=$ significant $(\mathrm{P}<0.05) ; * *=\operatorname{significant}(\mathrm{P}<0.01) ; * *=\operatorname{significant}(\mathrm{P}<0.001)$

Table 2: LVESD, LVDDD, LVFS and LVEF of all studied groups

\begin{tabular}{|c|c|c|c|c|}
\hline \multicolumn{2}{|c|}{$\begin{array}{ll} & \text { Groups } \\
\text { Parameters } & \\
\end{array}$} & $\begin{array}{l}\text { Group I } \\
\text { ( control) }\end{array}$ & $\begin{array}{l}\text { Group II } \\
\text { (HF) }\end{array}$ & $\begin{array}{c}\text { Group III } \\
\text { ( HF treated by vaspin) }\end{array}$ \\
\hline $\begin{array}{l}\text { LVESD } \\
(\mathrm{mm})\end{array}$ & $\bar{X} \pm S D$ & $2.55 \pm 0.1$ & $4.78 \pm 0.2^{\mathrm{a} * * *}$ & $3.21 \pm 0.2^{\mathrm{a}^{* * *} \mathrm{~b}^{* * *}}$ \\
\hline $\begin{array}{l}\text { LVEDD } \\
(\mathrm{mm})\end{array}$ & $\bar{X} \pm S D$ & $4.51 \pm 0.2$ & $6.79 \pm 0.1^{\mathrm{a}^{* * *}}$ & $5.02 \pm 0.2^{\mathrm{a}^{* * *} \mathrm{~b}^{* * *}}$ \\
\hline LVFS \% & $\bar{X} \pm S D$ & $43.54 \pm 2.9$ & $29.51 \pm 3.9^{\text {a }}$ & $36.19 \pm 2.5^{a * * *} b^{* * *}$ \\
\hline LVEF \% & $\overline{\mathrm{X}} \pm \mathrm{SD}$ & $75.19 \pm 2.1$ & $54.16 \pm 2^{\mathrm{a} * * *}$ & $68.07 \pm 3.1^{\mathrm{a}^{* * *} \mathrm{~b}^{* * *}}$ \\
\hline
\end{tabular}

$\mathrm{a}=$ versus group $\mathrm{I} ; \mathrm{b}=$ versus group II; $*=\operatorname{significant}(\mathrm{P}<0.05) ; * *=\operatorname{significant}(\mathrm{P}<0.01) ; * * *=\operatorname{significant}(\mathrm{P}<0.001)$ 
Table 3: Serum LDH, CPK-MB and cTnI in all studied groups

\begin{tabular}{|c|c|c|c|c|}
\hline \multicolumn{2}{|c|}{$\begin{array}{ll} & \text { Groups } \\
\text { Parameters } & \\
\end{array}$} & $\begin{array}{l}\text { Group I } \\
\text { ( control) }\end{array}$ & $\begin{array}{l}\text { Group II } \\
\text { (HF) }\end{array}$ & $\begin{array}{c}\text { Group III } \\
\text { ( HF treated by vaspin) }\end{array}$ \\
\hline $\begin{array}{l}\text { LDH } \\
(\mathrm{U} / \mathrm{L})\end{array}$ & $\bar{X} \pm S D$ & $120.73 \pm 17.6$ & $202.56 \pm 12.6^{\mathrm{a} * * *}$ & $155.86 \pm 19.7^{\mathrm{a} * * *} \mathrm{~b}^{* * *}$ \\
\hline CPK-MB (U/L) & $\overline{\mathrm{X}} \pm \mathrm{SD}$ & $101.09 \pm 12.5$ & $171.45 \pm 23.7^{\mathrm{a} * * *}$ & $144.02 \pm 19.9^{\mathrm{a}^{* * * *} \mathrm{~b}^{* * *}}$ \\
\hline $\mathrm{cTnI}(\mathrm{pg} / \mathrm{ml})$ & $\bar{X} \pm \mathrm{SD}$ & $1.48 \pm 0.2$ & $2.68 \pm 0.2^{\mathrm{a} * * *}$ & $1.99 \pm 0.2^{\mathrm{a}^{* * *} \mathrm{~b}^{* * *}}$ \\
\hline
\end{tabular}

$\mathrm{a}=$ versus group $\mathrm{I} ; \mathrm{b}=$ versus group $\mathrm{II} ; *=\operatorname{significant}(\mathrm{P}<0.05) ; * *=\operatorname{significant}(\mathrm{P}<0.01) ; * * *=\operatorname{significant}(\mathrm{P}<0.001)$

Table 4: Cardiac NO, TNFa, IL-6, MDA, SOD, CAT and GSH- Px in all studied groups

\begin{tabular}{|c|c|c|c|c|}
\hline \multicolumn{2}{|c|}{$\begin{array}{ll}\text { Parameters } & \text { Groups } \\
\end{array}$} & $\begin{array}{l}\text { Group I } \\
\text { ( control) }\end{array}$ & $\begin{array}{l}\text { Group II } \\
\text { (HF) }\end{array}$ & $\begin{array}{c}\text { Group III } \\
\text { ( HF treated by vaspin) }\end{array}$ \\
\hline $\begin{array}{c}\mathrm{NO}(\mu \mathrm{mol} / \mathrm{g} \\
\text { protein }\end{array}$ & $\bar{X} \pm \mathrm{SD}$ & $0.37 \pm 0.02$ & $0.33 \pm 0.02^{\mathrm{a}^{* *}}$ & $0.35 \pm 0.02^{\mathrm{b}^{*}}$ \\
\hline $\begin{array}{l}\mathrm{TNF} \alpha(\mathrm{ng} / \mathrm{mg} \\
\text { protein })\end{array}$ & $\bar{X} \pm S D$ & $123.18 \pm 5.89$ & $161.97 \pm 7.13^{a^{* * *}}$ & $152.21 \pm 4.65^{\mathrm{a}^{* * *} \mathrm{~b}^{* *}}$ \\
\hline $\begin{array}{l}\text { IL-6 }(\mathrm{pg} / \mathrm{mg} \\
\text { protein) }\end{array}$ & $\bar{X} \pm S D$ & $85.53 \pm 4.49$ & $103.9 \pm 6.62^{\mathrm{a}^{* * *}}$ & $95.49 \pm 4.95^{\mathrm{a} * * *} \mathrm{~b}^{* *}$ \\
\hline $\begin{array}{l}\text { MDA (nmol/ mg } \\
\text { protein ) }\end{array}$ & $\bar{X} \pm \mathrm{SD}$ & $0.48 \pm 0.02$ & $0.88 \pm 0.06^{\mathrm{a} * * *}$ & $0.63 \pm 0.04^{\mathrm{a}^{* * *} \mathrm{~b}^{* * *}}$ \\
\hline $\begin{array}{c}\mathrm{SOD}(\mathrm{U} / \mathrm{mg} \\
\text { protein })\end{array}$ & $\bar{X} \pm S D$ & $8.02 \pm 0.4$ & $5.48 \pm 0.5^{\mathrm{a} * * *}$ & $7.19 \pm 0.3^{\mathrm{a} * *} \mathrm{~b}^{* * *}$ \\
\hline $\begin{array}{l}\mathrm{CAT}(\mathrm{U} / \mathrm{mg} \\
\text { protein) }\end{array}$ & $\bar{X} \pm \mathrm{SD}$ & $16.56 \pm 0.7$ & $9.64 \pm 0.7^{\mathrm{a}^{* * *}}$ & $12.62 \pm 1.0^{\mathrm{a} * * *} \mathrm{~b}^{* * *}$ \\
\hline $\begin{array}{c}\text { GSH-Px }(\mathrm{U} / \mathrm{mg} \\
\text { protein) }\end{array}$ & $\bar{X} \pm S D$ & $6.94 \pm 0.5$ & $4.20 \pm 0.3^{\mathrm{a}^{* * *}}$ & $5.94 \pm 0.4^{\mathrm{a} * * *} \mathrm{~b}^{* * *}$ \\
\hline
\end{tabular}

$\mathrm{a}=$ versus group $\mathrm{I} ; \mathrm{b}=$ versus group II; $*=\operatorname{significant}(\mathrm{P}<0.05) ; * *=\operatorname{significant}(\mathrm{P}<0.01) ; * * *=\operatorname{significant}(\mathrm{P}<0.001)$
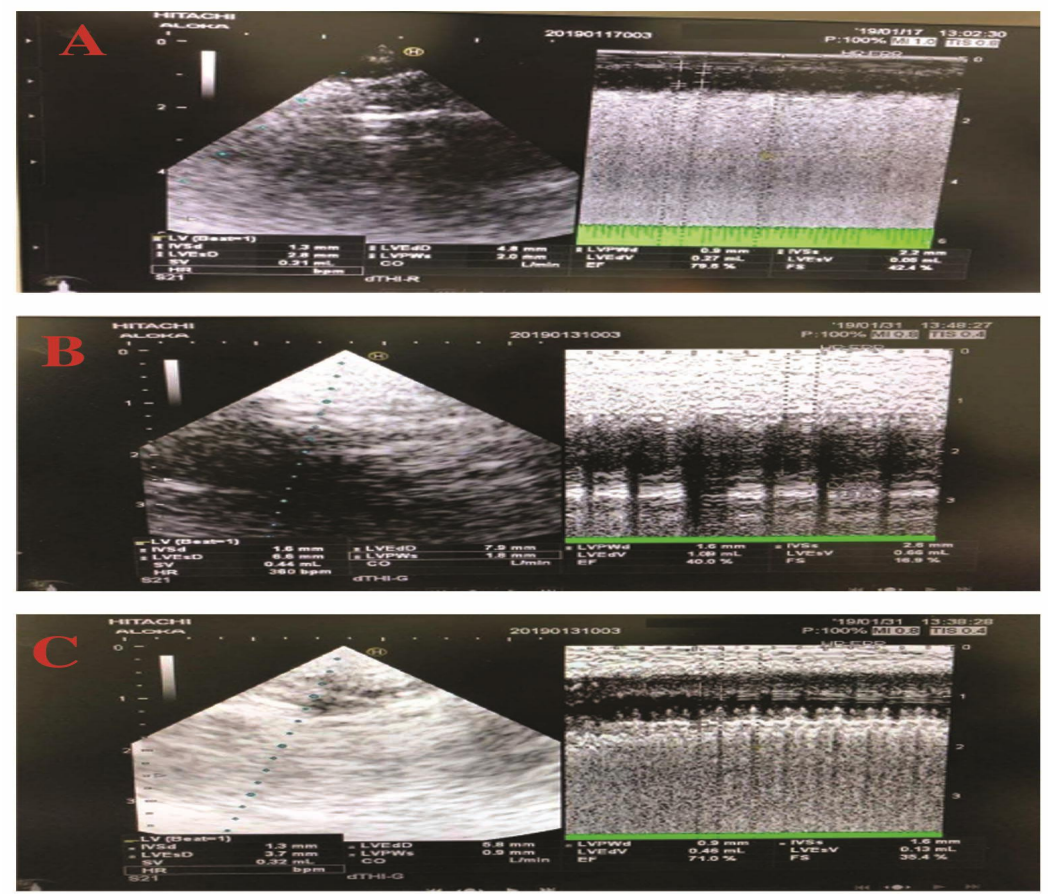

Figure $1(\mathrm{~A}, \mathrm{~B}, \mathrm{C})$ : Shows an example of echocardiography in groups I, II, III respectively 

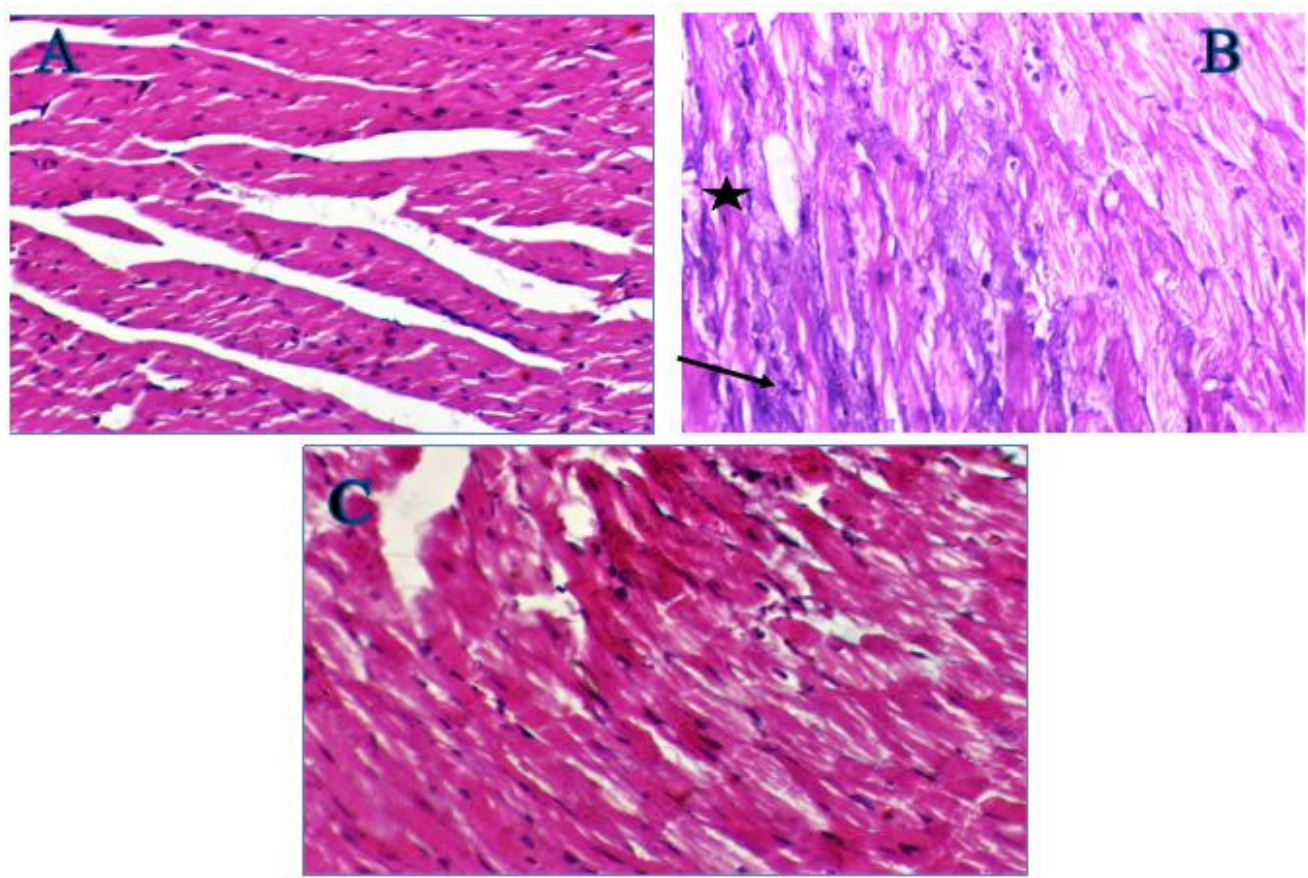

Figure 2: Photomicrograph (stained with Haematoxylin \& Eosin x400)

(A): normal cardiac tissue showing normal muscle fibers. (B): experimental isoproterenol-induced HF rat showing marked degeneration and distribution of myocytes with proliferation of intervening collagen fibers (star). Also, inflammatory cell infiltration was detected (arrow). (C): experimental isoproterenol-induced HF rat treated by vaspin showing mild degeneration of muscle fibers.
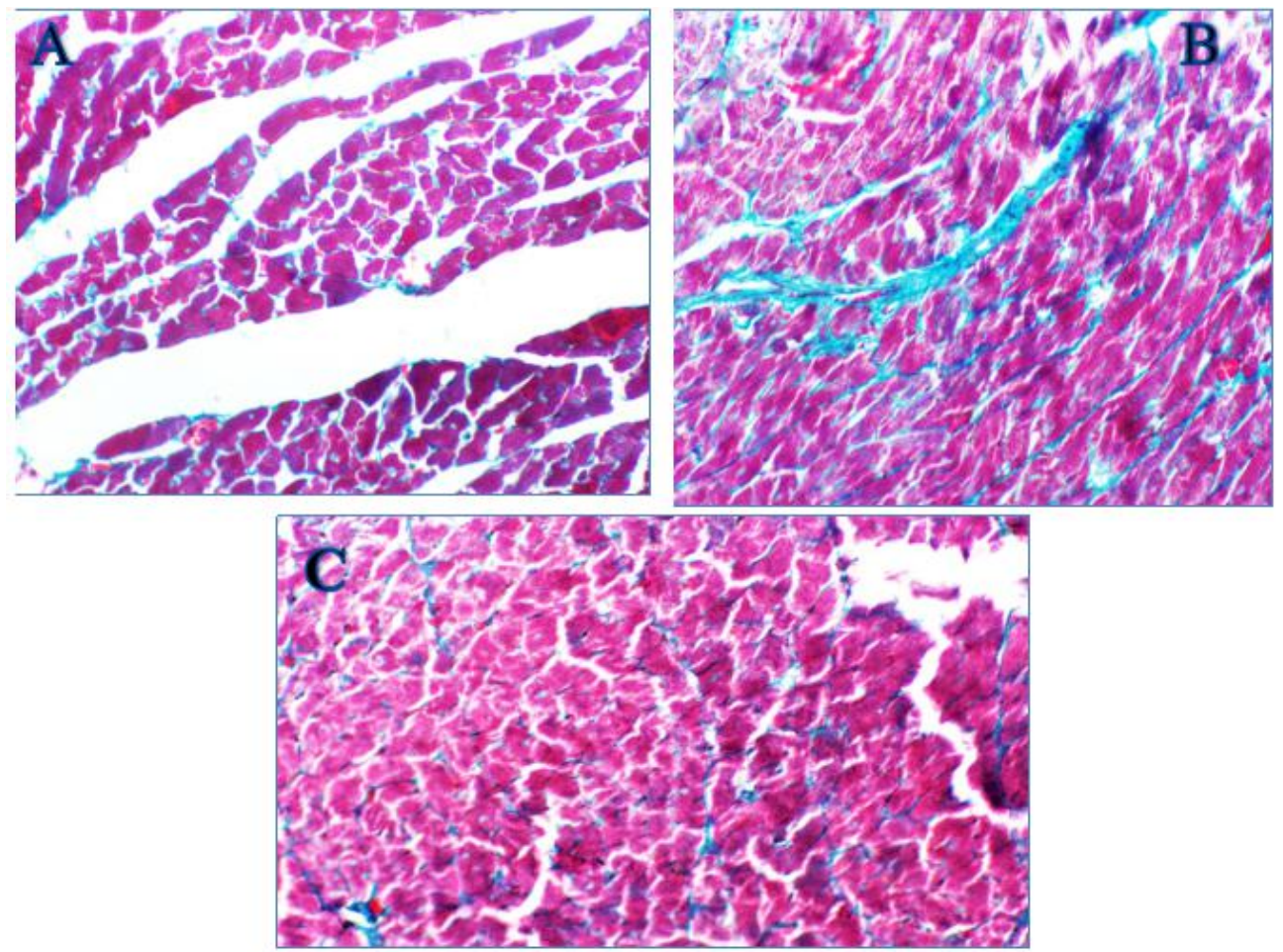

Figure 3: Photomicrograph (stained with Masson's Trichome x400)

(A):normal cardiac tissue showing normal delicate fibrous strands. (B): experimental isoproterenol-induced HF rat showing thick fibrous bands (C): experimental isoproterenol-induced HF rat treated by vaspin showing mild fibrosis. 


\section{Discussion}

The present study demonstrated that vaspin administration exerts an obvious cardioprotective effects as evidenced by altered hemodynamic changes, reduced serum concentrations of $\mathrm{LDH}$, CPK-MB and cTnI and attenuated the histopathological changes observed in isoproterenol-induced chronic heart failure in rats. The present investigation demonstrated that treatment with $5 \mathrm{mg} / \mathrm{kg}$ isoproterenol for 7 days produced cardiac hypertrophy in rats, as indicated by increased heart weight and HWI and caused significant increases of left ventricular end diastolic diameter (LVEDD) and left ventricular end systolic diameter (LVESD), but, decreased left ventricular fractional shortening (LVFS) and left ventricular ejection fraction (LVEF) which were in line with previous research results ${ }^{[16,31]}$.

Acute administration of isoproterenol increases cardiac contractility and heart rates, however following 7 days of isoproterenol adminstration, ejection fractions were decreased and left ventricular mass and end-diastolic volumes were increased. Downregulation of $\beta$-adrenergic receptors and decreased activity of adenylyl cyclase occur following chronic isoproterenol stimulation [32].

However, treatment with vaspin improved all previous changes induced by isoproterenol significantly. These results argued that vaspin could ameliorate the impairment in heart function caused by isoproterenol.

Isoproterenol is a well-known cardiotoxic agent as it induces cardiac hypertrophy, ventricular remodeling, myofibrillar degeneration of the myocardial tissue and fibrosis ${ }^{[4,33]}$. Isoproterenolinduced cardiac hypertrophy is a reliable, reproducible, and well-characterized model of cardiac hypertrophy that is associated with dysrhythmias, cardiomyocyte loss and fibrosis with progression to heart failure. In contrast to pressure overload induced heart failure, no surgical procedure is done and is associated with marked relative myocardial ischaemia ${ }^{[34]}$.

In agreement with the previous studies, our results demonstrated that isoproterenol significantly increased myofibrillar degeneration as evidenced by the significant increase in serum LDH, CPK-MB and cTnI and the myocardial degeneration \& fibrosis and increased infiltration of inflammatory cells observed in the histopathological examination. On the other hand, vaspin adminstration significantly alleviated the increased serum cardiac markers and these histophysiological changes which strongly demonstrated its protective effect on ventricular remodeling and hypertrophy in isoproterenol-induced $\mathrm{HF}$ rats.

The amount of cardiac enzymes including CPK-MB and LDH and cTnI; a low molecular weight and contractile protein, appear in serum proportional to the number of necrotic cells, which also reflects a nonspecific alteration in the plasma membrane integrity and/or permeability as a response to $\beta$-adrenergic stimulation ${ }^{[35]}$.

The reduction of ventricular contractility might be also ascribed to isoproterenol-induced oxidative stress and ischemic injury to chronotropic and inotropic function of heart [36]. Our results also demonstrated that ISO-treated rats showed increased levels of lipid peroxidation product (MDA) with decreased activity of various cardiac endogenous antioxidants like SOD, GPx and CAT than control rats. Similar findings were also noted by $\mathrm{Lu}$ et al. ${ }^{[21]}$. On the other hand, the levels of MDA were markedly decreased with a significant increase in cardiac antioxidants (SOD, CAT and GPx) activities in the vaspin treated ISO induced rats. The results of the present study also revealed that vaspin significantly alleviated the increased cardiac TNF- $\alpha$ and IL- 6 levels in ISO-induced CHF rats.

Nuclear factor like 2 (Nrf2) is a well-studied transcription factor that mediates antioxidant responses [37]. Under normal condition, it is maintained in the cytosol by Kelch-like ECHassociated protein 1 (Keap-1). In presence of ROS, certain cysteine residues in Keap-1 is oxidized, promoting its dissociation from $\mathrm{Nrf} 2$ followed by its translocation into nucleus to bind the antioxidant response elements (AREs) present in the promoter region of numerous genes mediating the antioxidant response [38]. ISO suppressed the $\mathrm{Nrf} 2$ activity below the standard level ${ }^{[39]}$.

On the other hand, vaspin inhibits the generation of ROS and proinflammatory molecules expression in vascular endothelial cells (ECs) and monocyte-EC adhesion ${ }^{[40]}$.Vaspin can inhibit the 
activation of nuclear factor kappa-light-chainenhancer of activated $\mathrm{B}$ cells $(\mathrm{NF}-\mathrm{\kappa B})$ mediated by proinflammatory factor TNF- $\alpha$ and IL- 1 and suppress the expression of the downstream molecules, protecting vascular ECs from inflammatory damage ${ }^{[41]}$.

During myocardial remodeling, NF- $\kappa \mathrm{B}$ induces the activation of cytokines, chemokines, and matrix metallo-proteinases; promoting inflammatory and fibrotic responses ${ }^{[42]}$. In vitro studies have also demonstrated that vaspin exerts anti-imflammatory, anti-apoptotic and antioxidant effects in vascular smooth muscle cells ${ }^{[10,11,12]}$.

Moreover, it was found that vaspin ameliorated in vivo myocardial ischemia/reperfusion injury and in vitro hypoxia-reoxygenation of cardiomyocyte cells in a dose-dependent manner and reduce the contents of interleukin- $1 \beta$ (IL-1 $\beta$ ), IL-18 and TNF- $\alpha$ in serum of rats and supernatant of cardiomyocyte cells ${ }^{[15]}$.

Our study had also revealed a significant decrease in cardiac NO in the isoproterenol group. This result was supported by the findings of Zhou et al., ${ }^{[4]}$ and Li et al. ${ }^{[43]}$. However, Karagöz et al. ${ }^{[31]}$ showed that emergence of HF via administration of isoproterenol led to an increase in NO expression. The discrepancy between the results may be due to differences in the designated dose, route and/or duration of administration of isoproterenol.

NO is solely generated in biological tissues by nitric oxide synthase (NOS) which metabolize arginine to citrulline with the NO molecule ${ }^{[44]}$. Lin et al. ${ }^{[45]}$ also reported that the expression of inducible NOS (iNOS) was up-regulated, endothelial NOS (eNOS) was down-regulated, and NO levels were decreased by ISO and that decreased nitric oxide level are implicated in cardiac hypertrophy induced by isoproterenol.

In fact, NO is necessary for normal cardiac physiology and has a protective effect in ischemic heart such that favorable effects of many drugs are thought to depend on upregulation of endothelial NOS and neuronal NOS, however, if overproduced in the failing heart as a result of increased activity and expression of the inducible isoform of NOS, this results in an un-coupling between NO and ROS leading to loss of antioxidant properties ${ }^{[46]}$.

vaspin administration significantly increased cardiac NO level in our results. This may also explain the improvement of cardiovascular function demonstrated in our study. Jung et al. ${ }^{[47]}$ also revealed that vaspin increased NO bioavailability through activating dimethylarginine dimethylaminohydrolase II (DDAH II) gene expression with subsequent decrease of asymmetric dimethylarginine (ADMA levels; an endogenous inhibitor of all types of nitric oxide synthases) in vascular endothelial cells. They also revealed that vaspin reduced ROS generation that might lead to decreased ADMA level and increased bioavailability of NO.

Taking the present findings together, it can be concluded that vaspin treatment can exert protective effects on isoproterenol-induced chronic heart failure in rats as indicated by improved cardiac function, ameliorated cardiac remodeling and hypertrophy and decreased cardiac injury biomarkers serum levels.

The probable mechanisms involved include increasing cardiac nitric oxide bioavailability, decreasing cardiac inflammation and inhibiting ROS generation and lipid peroxidation in heart.

\section{Acknowledgment:}

To Dr. Mona Mostafa Ahmed, Pathology Department, Faculty of Medicine, Zagazig University, for performing the histopatholgical studies.

\section{References}

1 Thompson KA, Bharadwaj P, Philip KJ, Schwarz ER. Heart failure therapy: beyond the guidelines. J Cardiovasc Med (Hagerstown) 2010; 11(12): 919-927 DOI: 10.2459/JCM.0b013e32833d3566

2 Johnson FL. Pathophysiology and etiology of heart failure. Cardiol Clin 2014; 32(1): 9-19, vii DOI: $\underline{10.1016 / j . c c l .2013 .09 .015}$

3 Rastogi A, Novak E, Platts AE, Mann DL. Epidemiology, pathophysiology and clinical outcomes for heart failure patients with a midrange ejection fraction. Eur J Heart Fail 2017; 19(12): 1597-1605 DOI: 10.1002/ejhf.879

4 Zhou R, Ma P, Xiong A, Xu Y, Wang Y, Xu Q. Protective effects of low-dose rosuvastatin on isoproterenol-induced chronic heart failure in 
rats by regulation of DDAH-ADMA-NO pathway. Cardiovasc Ther 2017; 35(2) [PMID: 27957828 DOI: 10.1111/1755-5922.12241]

5 Samson R, Ramachandran R, Le Jemtel TH. Systolic heart failure: knowledge gaps, misconceptions, and future directions. Ochsner J 2014; 14(4): 569-575 [PMID: 25598722 PMCID: PMC4295734]

6 Ranganathan P, Jayakumar C, Tang Y, Park KM, Teoh JP, Su H, Li J, Kim IM, Ramesh G. MicroRNA-150 deletion in mice protects kidney from myocardial infarction-induced acute kidney injury. Am J Physiol Renal Physiol 2015; 309(6): F551-558 DOI: 10.1152/ajprenal.00076.2015

7 D'Amario D, Cabral-Da-Silva MC, Zheng H, Fiorini C, Goichberg P, Steadman E, FerreiraMartins J, Sanada F, Piccoli M, Cappetta D, D'Alessandro DA, Michler RE, Hosoda T, Anastasia L, Rota M, Leri A, Anversa P, Kajstura J. Insulin-like growth factor-1 receptor identifies a pool of human cardiac stem cells with superior therapeutic potential for myocardial regeneration. Circ Res 2011; 108(12): $\quad$ 1467-1481 DOI: 10.1161/CIRCRESAHA.111.240648

8 Li L, Hao J, Jiang X, Li P, Sen H. Cardioprotective effects of ulinastatin against isoproterenol-induced chronic heart failure through the PI3KAkt, p38 MAPK and NFkappaB pathways. Mol Med Rep 2018; 17(1): 1354-1360 DOI: $10.3892 / \mathrm{mmr} .2017 .7934$

9 Suleymanoglu S, Tascilar E, Pirgon O, Tapan S, Meral C, Abaci A. Vaspin and its correlation with insulin sensitivity indices in obese children. Diabetes Res Clin Pract 2009; 84(3): 325-328 DOI: 10.1016/j.diabres.2009.03.008

10 Phalitakul S, Okada M, Hara Y, Yamawaki H. Vaspin prevents TNF-alpha-induced intracellular adhesion molecule-1 via inhibiting reactive oxygen species-dependent NF-kappaB and PKCtheta activation in cultured rat vascular smooth muscle cells. Pharmacol Res 2011; 64(5): 493-500 DOI: 10.1016/j.phrs.2011.06.001

11 Jung CH, Lee WJ, Hwang JY, Seol SM, Kim YM, Lee YL, Park JY. Vaspin protects vascular endothelial cells against free fatty acid-induced apoptosis through a phosphatidylinositol 3-kinase/Akt pathway. Biochem Biophys Res Commun 2011; 413(2): 264-269 DOI: $10.1016 /$ j.bbrc.2011.08.083

12 Li H, Peng W, Zhuang J, Lu Y, Jian W, Wei Y, $\mathrm{Li} \mathrm{W}, \mathrm{Xu} \mathrm{Y}$. Vaspin attenuates high glucoseinduced vascular smooth muscle cells proliferation and chemokinesis by inhibiting the MAPK, PI3K/Akt, and NF-kappaB signaling pathways. Atherosclerosis 2013; 228(1): $\quad$ 61-68

DOI: 10.1016/j.atherosclerosis.2013.02.013

13 Lin Y, Zhuang J, Li H, Zhu G, Zhou S, Li W, Peng $\mathrm{W}, \mathrm{Xu} \mathrm{Y}$. Vaspin attenuates the progression of atherosclerosis by inhibiting ER stress-induced macrophage apoptosis in apoE/ mice. Mol Med Rep 2016; 13(2): 1509-1516 DOI: $\underline{10.3892 / \mathrm{mmr} .2015 .4708}$

14 Kobat MA, Celik A, Balin M, Altas Y, Baydas A, Bulut M, Aydin S, Dagli N, Yavuzkir MF, Ilhan $\mathrm{S}$. The investigation of serum vaspin level in atherosclerotic coronary artery disease. J Clin Med Res 2012; 4(2): 110-113 DOI: $10.4021 /$ jocmr841w

15 Yuan L, Dai X, Fu H, Sui D, Lin L, Yang L, Zha P, Wang X, Gong G. Vaspin protects rats against myocardial ischemia/reperfusion injury (MIRI) through the TLR4/NF-kappaB signaling pathway. Eur J Pharmacol 2018; 835: $\quad 132-139$

DOI: 10.1016/j.ejphar.2018.07.052

16 Wang QW, Yu XF, Xu HL, Zhao XZ, Sui DY. Ginsenoside $\mathrm{Re}$ Improves IsoproterenolInduced Myocardial Fibrosis and Heart Failure in Rats. Evid Based Complement Alternat Med 2019; 2019: 3714508 DOI: $\underline{10.1155 / 2019 / 3714508}$

17 Kameshima S, Sakamoto Y, Okada M, Yamawaki H. Vaspin prevents elevation of blood pressure through inhibition of peripheral vascular remodelling in spontaneously hypertensive rats. Acta Physiol (Oxf) 2016; 217(2): 120-129 DOI: 10.1111/apha.12636

18 Kachmar, J.; Moss, D. Enzymes. In Fundamentals of clinical chemistry. Pbl. Saunders, Philadelphia, 1976, pp. 652- 6603.

19 Wu AH, Gornet TG, Bretaudiere JP, Panfili PR. Comparison of enzyme immunoassay and immunoprecipitation for creatine kinase MB in 
diagnosis of acute myocardial infarction. Clin Chem 1985; 31(3): 470-474 [PMID: 3882278]

20 Etievent JP, Chocron S, Toubin G, Taberlet C, Alwan K, Clement F, Cordier A, Schipman N, Kantelip JP. Use of cardiac troponin I as a marker of perioperative myocardial ischemia. Ann Thorac Surg 1995; 59(5): 1192-1194 DOI: $10.1016 / 0003-4975(95) 00129-9$

21 Lu, H.; Tan, Y.; Yang, L.; Dong, H.; Liao, Y.; Cao, S.; Fu, S. Cardioprotective Efficiency of Tangeretin Against Heart Failure Induced by Isoproterenol in Rats. International Journal of Pharmacology., 2018, 14(8) 1145-1152 DOI: 10.3923/ijp.2018.1145.1152.

22 Kakkar P, Das B, Viswanathan PN. A modified spectrophotometric assay of superoxide dismutase. Indian J Biochem Biophys 1984; 21(2): 130-132

23 Ohkawa H, Ohishi N, Yagi K. Assay for lipid peroxides in animal tissues by thiobarbituric acid reaction. Anal Biochem 1979; 95(2): 351358 DOI: 10.1016/0003-2697(79)90738-3

24 Boveris A, Chance B. The mitochondrial generation of hydrogen peroxide. General properties and effect of hyperbaric oxygen. Biochem J 1973; 134(3): 707-716 DOI: $\underline{10.1042 / \text { bj1340707 }}$

25 Paglia DE, Valentine WN. Studies on the quantitative and qualitative characterization of erythrocyte glutathione peroxidase. J Lab Clin Med 1967; 70(1): 158-169 [PMID: 6066618]

26 Bonavida B. Immunomodulatory effect of tumor necrosis factor. Biotherapy 1991; 3(2): 127-133 [PMID: 2054253]

27 Wang B, Li L, Jin P, Li M, Li J. Hesperetin protects against inflammatory response and cardiac fibrosis in postmyocardial infarction mice by inhibiting nuclear factor kappaB signaling pathway. Exp Ther Med 2017; 14(3): 2255-2260 DOI: 10.3892/etm.2017.4729

28 Ghasemi A, Mehrazin F, Zahediasl S. Effect of nitrate and L-arginine therapy on nitric oxide levels in serum, heart, and aorta of fetal hypothyroid rats. J Physiol Biochem 2013; 69(4): 751-759 DOI: $10.1007 / \mathrm{s} 13105-013-$ $\underline{0251-\mathrm{X}}$

29 Bancroft, JD.; Gamble, M. Theory and Practice of Histological Techniques.5th ed., Churchill Living Stone. London. 2002; pp: 150-152.
30 Schroeder AM, Wang HB, Park S, Jordan MC, Gao F, Coppola G, Fishbein MC, Roos KP, Ghiani CA, Colwell CS. Cardiac Dysfunction in the BACHD Mouse Model of Huntington's Disease. PLoS One 2016; 11(1): e0147269 DOI: 10.1371/journal.pone.0147269

31 Karagoz A, Kesici S, Vural A, Usta M, Tezcan B, Semerci T, Teker E. Cardioprotective effects of Viscum album L. ssp. album (Loranthaceae) on isoproterenol-induced heart failure via regulation of the nitric oxide pathway in rats. Anatol J Cardiol 2016; 16(12): 923-930 DOI:

10.14744/AnatolJCardiol.2016.6780

32 Takeshita D, Shimizu J, Kitagawa Y, Yamashita D, Tohne K, Nakajima-Takenaka C, Ito $\mathrm{H}$, Takaki $\mathrm{M}$. Isoproterenol-induced hypertrophied rat hearts: does short-term treatment correspond to long-term treatment? $\boldsymbol{J}$ Physiol Sci 2008; 58(3): 179-188 DOI: 10.2170/physiolsci.RP004508

33 Patel V, Upaganlawar A, Zalawadia R, Balaraman R. Cardioprotective effect of melatonin against isoproterenol induced myocardial infarction in rats: A biochemical, electrocardiographic and histoarchitectural evaluation. Eur J Pharmacol 2010; 644(1-3): 160-168 DOI: 10.1016/j.ejphar.2010.06.065

34 Krenek P, Kmecova J, Kucerova D, Bajuszova Z, Musil P, Gazova A, Ochodnicky P, Klimas J, Kyselovic J. Isoproterenol-induced heart failure in the rat is associated with nitric oxidedependent functional alterations of cardiac function. Eur J Heart Fail 2009; 11(2): 140146 DOI: $10.1093 /$ eurjhf/hfn026

35 Keravis $\mathrm{T}$, Lugnier $\mathrm{C}$. Cyclic nucleotide phosphodiesterase (PDE) isozymes as targets of the intracellular signalling network: benefits of PDE inhibitors in various diseases and perspectives for future therapeutic developments. Br J Pharmacol 2012; 165(5): 1288-1305 DOI: $\underline{10.1111 / \mathrm{j} .1476-}$ 5381.2011.01729.x

36 Ojha S, Nandave M, Arora S, Arya DS. Effect of isoproterenol on tissue defense enzymes, hemodynamic and left ventricular contractile function in rats. Indian $\boldsymbol{J}$ Clin Biochem 2010; 25(4): 357-361 DOI: $\underline{10.1007 / \mathrm{s} 12291-010-}$ 0070-6 
37 Xing Y, Niu T, Wang W, Li J, Li S, Janicki JS, Ruiz S, Meyer CJ, Wang XL, Tang D, Zhao Y, Cui T. Triterpenoid dihydro-CDDOtrifluoroethyl amide protects against maladaptive cardiac remodeling and dysfunction in mice: a critical role of Nrf2. PLoS One 2012; 7(9): e44899 DOI: 10.1371/journal.pone.0044899

38 Bryan HK, Olayanju A, Goldring CE, Park BK. The Nrf2 cell defence pathway: Keap1dependent and -independent mechanisms of regulation. Biochem Pharmacol 2013; 85(6): 705-717 DOI: 10.1016/j.bcp.2012.11.016

39 Santosh, K.; Jahangir, MA.; Pankaj, P.; Subir, KM.; Shyamal, KG. Terminalia arjuna (Roxb.) Reverses the Molecular Signature of Fibrosis Induced by Isoproterenol in Rat Heart. $\boldsymbol{A m} \boldsymbol{J}$ Phytomed Clin Ther., 2017, 5 (3):22. DOI:10.21767/2321-2748.100335.

40 Jung CH, Lee MJ, Kang YM, Lee YL, Yoon HK, Kang SW, Lee WJ, Park JY. Vaspin inhibits cytokine-induced nuclear factor-kappa $B$ activation and adhesion molecule expression via AMP-activated protein kinase activation in vascular endothelial cells. Cardiovasc Diabetol 2014; 13: 41 DOI: 10.1186/1475-2840-13-41

41 Liu S, Dong Y, Wang T, Zhao S, Yang K, Chen $\mathrm{X}$, Zheng C. Vaspin inhibited proinflammatory cytokine induced activation of nuclear factor-kappa B and its downstream molecules in human endothelial EA.hy926 cells. Diabetes Res Clin Pract 2014; 103(3): 482-488 DOI: 10.1016/j.diabres.2013.12.002
42 Turner NA,Porter KE. Regulation of myocardial matrix metalloproteinase expression and activity by cardiac fibroblasts. IUBMB Life 2012; 64(2): 143-150 DOI: 10.1002/iub.594

43 Li X, Wang X, Guo Y, Deng N, Zheng P, Xu Q, Wu Y, Dai G. Regulation of endothelial nitric oxide synthase and asymmetric dimethylarginine by matrine attenuates isoproterenol-induced acute myocardial injury in rats. J Pharm Pharmacol 2012; 64(8): 1107-1118 DOI: $\underline{10.1111 / \mathrm{j} .2042-}$ 7158.2012.01502.x

44 Welch G, Loscalzo J. Nitric oxide and the cardiovascular system. J Card Surg 1994; 9(3): 361-371 [PMID: 8054733]

45 Lin Y, Wang LN, Xi YH, Li HZ, Xiao FG, Zhao YJ, Tian Y, Yang BF, Xu CQ. L-arginine inhibits isoproterenol-induced cardiac hypertrophy through nitric oxide and polyamine pathways. Basic Clin Pharmacol Toxicol 2008; 103(2): 124-130 DOI: 10.1111/j.1742-7843.2008.00261.x

46 Vanhoutte PM, Gao Y. Beta blockers, nitric oxide, and cardiovascular disease. Curr Opin Pharmacol 2013; 13(2): 265-273 [PMID: 23294896 DOI: 10.1016/j.coph.2012.12.002]

47 Jung $\mathrm{CH}$, Lee WJ, Hwang JY, Lee MJ, Seol SM, Kim YM, Lee YL, Kim HS, Kim MS, Park JY. Vaspin increases nitric oxide bioavailability through the reduction of asymmetric dimethylarginine in vascular endothelial cells. PLoS One 2012; 7(12): e52346 DOI: 10.1371/journal.pone.0052346 